\title{
UMA ANÁLISE DE CASO DOS JULGAMENTOS DO TRIBUNAL DO JÚRI DA COMARCA DA PALHOÇA/SC
}

\begin{abstract}
Luciano Góes ${ }^{1}$
Gustavo Noronha de Ávila

Resumo: Não existe consenso na doutrina pátria sobre a origem da instituição do tribunal do júri. Inobstante à sua origem exata, o tribunal do júri nasce, exatamente intentando limitar o poder vingativo do soberano. Em que pese o lapso temporal que separa as realidades, a instituição se embasa nas mesmas premissas, mantendo a ilusão de alcance da justiça. Neste diapasão, o júri, nos moldes atuais, não se coaduna com as garantias professadas por um Estado Democrático de Direito, fundando suas decisões na subjetividade que potencializa o julgamento do autor do fato, resultando, pois, em uma seletividade inquisitiva, baseada no estereótipo do "criminoso".
\end{abstract}

Palavras-chave: Tribunal do Júri. Processo penal. Criminologia. Seletividade. Estereótipo.

\section{INTRODUÇÃO}

Em toda a história da humanidade, não faltam períodos nos quais a força do soberano se demonstrava sobre o corpo do acusado de cometimento de delitos que eram vistos como ofensa não apenas ao ordenamento legal, mas ao próprio monarca, eram os delitos chamados de "lesa-majestade".

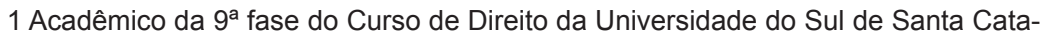
rina - UNISUL. E-mail: Iglucianogoes@gmail.com

2 Professor do Centro Universitário Ritter dos Reis, em Porto Alegre e Canoas (RS). Doutorando e Mestre em Ciências Criminais pela Pontifícia Universidade Católica do Rio Grande do Sul. Advogado. E-mail: gusnavila@gmail.com 
A partir desta conscientização e da normatização de direitos, houve a necessidade, mediante o brado social, de conceber aos cidadãos comuns o julgamento de crimes cometidos por populares, fazendo-os acreditar que participando diretamente dos julgamentos a justiça (deles) seria alcançada, cessando o clamor e inebriando a população com uma política de "pão e circo".

Nesse contexto, surgiram os julgamentos populares, observados nas mais diversas culturas, sempre vislumbrando o alcance da justiça ditada por uma ilusória igualdade existente entre os pares dos acusados, pois a justiça e as prerrogativas necessárias para seu alcance adviriam da percepção e conhecimento da realidade vivenciada por julgadores e julgados, nestes moldes, o júri se espalhou por todo o mundo.

Neste diapasão, considerando-se todas as construções humanísticas em relação à busca pela justiça e a consolidação dos direitos humanos, a instituição do tribunal do júri, nos moldes como é estabelecido atualmente, pretende, ainda, alcançar uma justiça, tendo por justificativa, a prolação da sentença por juízes leigos, iguais ao acusado, consolidando a participação direta e democrática dos cidadãos no exercício jurisdicional.

Outrossim, surge o questionamento: o Conselho de Sentença, a partir das bases constitucionais e legais estabelecidas ao júri popular, leva em consideração os fatores extraprocessuais, ou seja, os aspectos pessoais do acusado, no momento de sua decisão?

Impulsionados pela refutação ou ratificação dos motivos e objetivos primários da instituição, nos propomos a estudar o júri, desde a suas premissas constitucionais até os julgamentos em plenário, verificando as realidades emanadas pelo conselho de sentença, no que concerne aos aspectos sócio-econômicos e físicos dos acusados, sob a ótica da seletividade penal de Alessandro Baratta e a égide garantista de Luigi Ferrajoli.

A pesquisa foi realizada em campo, na Comarca de Palhoça, Santa Catarina, de forma qualitativa, utilizando o procedi- 
mento técnico de levantamento, com o emprego de um questionário a 51 jurados que formaram os Conselhos de Sentença nos processos dos crimes de homicídios dolosos, consumados, julgados entre 02/09/2010 à 17/03/2011. Foi empregado o método dedutivo, e a análise dos dados coletados, se operou de forma estatística.

\section{O TRIBUNAL DO JÚRI: DA ORIGEM AOS DIAS ATUAIS}

As origens fundantes da instituição do tribunal do júri são tão antigas que não há registros que a demonstrem com precisão. Nessa linha de incerteza, a estruturação deste remoto instituto se apresenta, a priori, seguindo um nexo de raciocínio temporal, na antiguidade de povos e civilizações que datam antes do nascimento de Cristo.

Assim, Guilherme de Souza Nucci (2008, p. 41) aponta a existência em Atenas, Grécia, desde o Século IV a.C., o Tribunal de Heliastas (jurisdição comum, composta por cidadãos do povo ), que se reunia em praça pública. Mauro Fonseca Andrade (2009, p. 51-54) preleciona que Sólon (por volta de 640 a.C.), com o intuito de apaziguar os conflitos sociais, promoveu várias mudanças, entre elas, a nova Constituição cuja missão era promover a democracia ateniense, substituiu o Conselho do Areópago (guardião da Constituição e das leis, formado por pessoas notáveis e ricas se tornavam magistrados vitalícios ligados ao rei), que servia à manutenção da estrutura estamental da sociedade grega, pelos Heliastas, pois a sociedade deveria ser uma só, e os cidadãos, por sentirem a dor do outro, fariam justiça.

Em Esparta, segundo Paulo Rangel (2008, p. 528), existiam os Éforos (juízes do povo); na Palestina, ainda segundo o autor, existia o Tribunal dos Vinte e três nas vilas com população superior a 120 famílias. "Esses tribunais conheciam processos criminais relativos a crimes puníveis com a pena de morte. Seus membros eram tirados dentre os padres, os levitas e os principais chefes de famílias de Israel”. 
Inobstante à sua origem exata, o tribunal do júri nasce, exatamente intentando limitar o poder vingativo do soberano, monarca ou déspota, e retirando o poder de decisão destes ou de quem, por delegação, agia em seu nome, visto que, os delitos eram concebidos como lesa-majestade, conforme estabelece Michel Foucault (1999, p. 41), uma vez que "o crime, além de sua vítima imediata, ataca o soberano; ataca-o pessoalmente, pois a lei vale como a vontade do soberano; ataca-o fisicamente, pois a força da lei é a força do príncipe”, o que justificava a imposição de toda força soberana em forma de suplícios.

A maioria dos doutrinadores indica que foi na Inglaterra de Henrique II (1154-1189) que se desenvolveu a instituição do júri, da qual se originam as raízes da Instituição brasileira atual, pois, durante seu reinado o Concílio de Latrão substituiu os Ordalios que determinava aos homens bons da comunidade o julgamento de um cidadão apontado como autor de um crime para, sob juramento, realizar o julgamento em um órgão colegiado, instituindo assim o Jury.

Paulo Rangel (2007, p. 482), lembra que a Magna Carta supracitada, foi resultado de "[...] um acordo entre a nobreza e o monarca daquele país, do qual, logicamente, o povo não participou [...]", e ao se afirmar que os julgamentos iam ser proferidos pelos pares do infrator, deve-se visualizar que quem julgaria eram os nobres, não os populares.

Mais tarde, em 1.215, a instituição ganhou status constitucional daquele país, que, assim preordenou: "Nenhum homem livre será encarcerado ou exilado, ou de qualquer forma destruído, a não ser pelo julgamento legal de seus pares e por lei do país”. Uma vez elencada na Carta Magna, o tribunal popular foi amplamente difundido e inserido nos diversos ordenamentos jurídicos mundiais.

Atualmente, a Constituição da República Federativa do Brasil, reconhece a instituição de júri popular, em seu Art. 5º inc. XXXVIII:

É reconhecida a instituição do júri, com a organização que lhe der a lei, assegurados: 

a) a plenitude de defesa;
b) o sigilo das votações;
c) a soberania dos veredictos;
d) a competência para o julgamento dos crimes dolosos contra a vida.

Aramis Nassif (2008, p. 34-35), defende que "a sensibilidade e compreensão popular afronta a norma tipificadora, rompe com a armadura jurídica que obstaculizou ao juiz uma decisão mais consentânea com a realidade social e, ao fim, transferindo a responsabilidade aos membros da sociedade, faz-se justiça".

"Mil perdões pelo meu senso / de criticar / mas existo,
logo penso / e pensando vou falar [...]".
("Aos novos compositores", Arlindo Cruz)

\section{CRÍTICAS AO TRIBUNAL DE JÚRI}

Neste capítulo, analisaremos de forma crítica os julgamentos populares, iniciando com as premissas constitucionais do júri e findando com alguns pressupostos legais decorrentes do septuagenário Código de Processo Penal. Neste prisma, procuraremos demonstrar como a instituição se afasta do texto constitucional em matéria de direitos e garantias.

\subsection{Os Pressupostos Constitucionais da Instituição}

Como forma de estudarmos a instituição do júri, analisaremos o texto constitucional que estabelece suas premissas básicas, como sucedâneo de fonte hierárquica do ordenamento jurídico e legítima dos direitos e garantias.

\subsubsection{A Plenitude de Defesa}

Guilherme de Souza Nucci (2008, p. 25) ensina que existe uma diferença substancial entre ampla defesa e plenitude de 
defesa, pois "amplo é algo vasto, largo, copioso, enquanto pleno equivale a completo, perfeito, absoluto", restando assim, no que tange ao tribunal de júri, a busca de uma defesa perfeita, completa em benefício dos réus, onde o princípio da ampla defesa se encontra implícito na plenitude de defesa.

Neste contexto, em Plenário, os atores judiciais podem valer-se de todas as formas lícitas que embasam suas teses, incluindo a encenação que transforma a liberdade do acusado e a vida da vítima em um roteiro de telenovela, o Plenário é o cenário e os atores, o membro do Ministério Público e o Advogado de defesa, podendo ser dramático, trágico ou mesmo cômico.

Para Aramis Nassif (2008, p. 97), essa "teatralização" é incita ao júri, uma vez que estão conjugados em Plenário, as emoções, os sentimentos e as paixões humanas, que podem ser despertadas e até mesmo direcionadas, dependendo da atuação dos atores em prol d absolvição ou condenação. Assim, o julgamento em plenário se iguala à uma peça cênica, induzindo, convencendo e impressionando os jurados, pois "[...] a interpretação no palco ou no plenário serve para informar, sensibilizar, emocionar e envolver tanto o espectador no teatro como o jurado no tribunal do júri [...]”.

\subsubsection{O Sigilo das Votações}

O sigilo das votações é a garantia que os jurados possuem de não serem identificados, ao depositarem seus votos, e assim, não sofrerem pressões, retaliações ou ainda, serem alvo de vingança.

Não se trata de desrespeito ao Princípio da Publicidade, tendo em vista que o que é sigiloso é o voto dos jurados e somente este, a votação se dá em sala especial e na sua falta, no próprio Plenário, sendo que neste caso, o Juiz Presidente determinará a saída do público, restando presentes para a votação o Juiz Presidente, os jurados, o membro do Ministério Público, 
o defensor do acusado, o escrivão, os oficiais de justiça, o assistente de acusação e o querelado (se for o caso), e ainda é permitida a presença de acadêmicos de direito.

A respeito deste postulado, Eugênio Pacelli de Oliveira (2008, p. 565), lembra que este sigilo tutela a decisão colegiada nos contornos do júri, haja vista que "[...] impõe o dever de silêncio (a regra da incomunicabilidade) entre os jurados, de modo a impedir que qualquer um deles possa influir no ânimo e no espírito dos demais, para fins da formação do convencimento acerca das questões de fato e de direito em julgamento".

\subsubsection{A Soberania dos Veredictos}

No que concerne a este preceito, Fernando da Costa Torinho Filho (2008, p. 307) ensina que a soberania do júri, estabelecida pelo legislador ordinário de 1946, não pode ser levada ao literalismo, o que traduziria uma decisão absoluta. O doutrinador reconhece a soberania como um sucedâneo da democracia postulada pelo júri, haja vista que:

[...] Tribunal leigo sem soberania (pelo menos dentro dos seus limites intransponíveis) não passa, como se diz numa linguagem moderna, de órgão cafona, ridículo e burlesco, servindo, apenas, para satisfazer a uma platéia ávida de um picaresco exibicionismo oratório, com irritante verbiagem. Ou ele existe para tutelar mais ainda o jus libertatis e, nesse caso, a soberania das decisões, ainda que parcimoniosa, é consubstancial à Instituição, ou, então, não passa de simples órgão jurisdiconal. (TOURINHO FILHO, 2008, p. 309)

Destarte, dos julgamentos de seus pares, o réu apenas pode recorrer por meio de revisão criminal, nos termos do Art. 621 do CPP, e em sede de apelação. Evidencia-se que a única possibilidade de revisão da manifestação de vontade dos jurados é quando esta resultar, manifestamente, contrária à prova dos autos. Em referência à soberania do julgamento popular, 
expressa Aury Lopes Júnior (2009, P. 312) que os jurados possuem o poder de "[...] tornar o quadrado, redondo, com plena tolerância dos Tribunais e do senso comum teórico [...]”.

Nesta toada, o princípio do duplo grau de jurisdição fica, evidentemente, reduzido diante da soberania inerente aos veredictos do júri, de modo que nenhum órgão jurisdicional pode substituir a "vontade popular", sendo cabível, sempre que possível nos termos e limites da lei, a interposição de apelação, que, é de se explicitar, não irá possibilitar a análise do mérito por juízes togados, mas somente determinará um novo pronunciamento por outro conselho de sentença.

Outrossim, não se pode conceber que decisões que impõem a privação da liberdade alheia sejam emanadas sem estarem presentes os princípios da motivação, da publicidade e do duplo grau de jurisdição, consideradas aqui, em última análise, como decorrência do princípio da ampla defesa, inerentes a ocorrência de erros "naturais" ínsitos à pessoa humana, posto que, como alerta Fernando da Costa Tourinho Filho (2008, p. 315) se tais "[...] decisões fossem proferidas por deuses ou semideuses, trariam elas a nota da infalibilidade” , mas quem as profere são homens comuns, iguais em sua possibilidade de falibilidade humana.

Não obstante a probabilidade de erros, materiais e de interpretações, a soberania popular, em que pese ser apontada como postulado democrático da instituição, em consonância com os outros pressupostos, mitiga o sistema constitucional de tutela dos direitos fundamentais, pois, como alerta o próprio Fernando da Costa Tourinho Filho (2008, p. 305), "os jurados têm inteira liberdade de julgar, e o fazem de acordo com a sua consciência, sem ficar adstritos à lei e à prova”, colocando em "xeque" a possibilidade supracitada de interposição de apelação, que somente poderá ocorrer, repita-se, quando a decisão for contrária aos autos.

Desta monta, oportuna se faz a interrogação: E quando a condenação se fundar em prova não trazida à lume no processo? 


\subsubsection{A Competência}

A competência, absoluta em razão da matéria, define o Júri como Juiz natural dos crimes dolosos contra a vida, excluindo os culposos, que se houver a desclassificação por parte do conselho de sentença, caberá ao juiz presidente o julgamento.

No rol de crimes contra a vida, estão os crimes previstos no CPP entre o art. 121 (homicídio) ao art. 127 (aborto), vinculando-se também, os delitos conexos a estes, por força de atração estabelecida pelos concursos materiais e formais, respectivamente previstos nos arts. 69 e 70, e continuação delitiva (art. 71) todos do Código Penal. Decorrente do texto constitucional, não há óbices para a competência do júri ser ampliada.

\subsection{Os Pressupostos Legais da Instituição}

A organização da instituição, conforme a Constituição, depende de lei ordinária e mutável por meio de vontade política, que lhe atribui outras peculiaridades.

Assim, o Decreto-Lei no 3.689/41 (Código de Processo Penal), de origem fascista, influência do Código Rocco italiano de Mussolini, regulamenta o júri, que compreende os artigos 406 ao 497.

\subsubsection{A (in)dependência}

O princípio da independência diz com relação à pressão política e social, intenta assim, afastar qualquer influência nos julgamentos. Luigi Ferrajoli (2002, p. 468-469), atribui o princípio ao pensamento jurídico iluminista e à obrigatória separação de Poderes, pois é dela que se garante a isenção de pressões e influências no ato judicante, haja vista que a independência, uma das garantias orgânicas inerentes à magistratura, é uma aquisição do moderno Estado de Direito, resultado de um lento processo histórico de substituição do juiz investido ao juiz delegado.

Configura-se, assim, como uma garantia funcional aos cidadãos pois é essencial a tutela dos direitos contra todos os 
poderes. Deveras, é nessa possibilidade de julgar sem sofrer qualquer pressão, influência ou ameaça ao decidir um processo, é que a independência judicante deveria se limitar. Nesta esteira, diz o doutrinador:

Se a legitimidade do juízo se funda na verdade processual, cuja decisão depende da determinação semântica das leis e, portanto, dos vínculos estritamente legais da jurisdição, é claro que ela exige a independência do juiz tanto quanto seu distanciamento, em garantia a imparcialidade e, portanto, da igualdade dos cidadãos. Por outro lado, se o juízo é voltado a impedir arbítrios ou abusos potestativos sobre as liberdades individuais por parte dos poderes de governo, a independência dos juízes garante uma justiça não subordinada à razão de Estado ou a interesse políticos contingentes. Os fundamentos externos ou políticos da independência são em suma os mesmos - verdade e liberdade - que legitimam a jurisdição. (FERRAJOLI, 2006, p. 468)

Deste prisma, o júri é influenciado por preceitos externos, pois estão despidos da mínima base axiológica jurídica necessária para sopesar os bens jurídicos confrontados na lide e carentes da compreensão das "leis sociais", que de acordo com Alessandro Baratta (2002, p. 22) são derivadas do estudo da sociologia teórica que possibilita aos operadores do direito uma compreensão dos fenômenos ou comportamentos empiricamente não observáveis, "[...] mas que são necessárias para interpretar os fenômenos".

Todavia, a dependência não deriva apenas de aspectos políticos, sociais ou culturais que se auxiliam na construção de conceitos pré-concebidos situados no inconsciente dos jurados, influenciam ainda nos julgamentos, a decisão da pronúncia, por se tratar de um ato do juiz-presidente, que simboliza a própria justiça.

Por fim, a influência midiática coloca em xeque a independência necessária da instituição, pois, os jurados, em geral, são 
declinados a condenação diante do apelo midiático, pois, como aponta Aury Lopes Júnior (2009, p. 309), "os leigos estão muito mais suscetiveis a pressões e influências políticas, econômicas e, principalmente, midiática, na medida em que carecem das garantias orgânicas da magistratura”.

\subsubsection{A Incomunicabilidade}

A incomunicabilidade entre os jurados que compõe o conselho de sentença, pode, em uma análise superficial e descurada, ser atribuída ao sigilo das votações, que advém da imposição constitucional.

Entretanto, o princípio ora em comento, não se confunde com este, para muito além do sigilo dos votos compreendemos a proibição de comunicação entre os jurados ou com outrem, posto que é um verdadeiro instrumento na tentativa de irracional de censurar e controlar as idéias ou opiniões que possam eventualmente surgir no seio da instituição e se espalhar, contrariando a função original do júri e seus objetivos perpetrados historicamente.

Desta feita, o silêncio imposto aos jurados é "[...] uma censura imposta como a mais forte arma que os regimes totalitários utilizam, desde a Antiguidade, para impedir a propagação de idéias que podem pôr em dúvida a organização do Poder e o seu maior rigor [...]" (RANGEL, 2007, p.497).

A comunicação possibilitaria a discussão obrigatória que todo problema complexo social preordena, pois, por evidente que, as discussões responsáveis facultam as partes envolvidas a encontrarem a solução mais adequada, minorando os riscos e danos aparentes.

Além de se mostrar como uma involução, o aprisionamento intelectual impede-nos de compartilhar opiniões, ponto de vistas, detalhes que não foram percebidos, questionamentos, impedidos de serem persuadidos por um eventual pensamento racional. Nossas verdades acabam por se tornar absolutas, pois não se 
contrastam com outras verdades que fazem parte do mundo exterior. Eis os motivos da incomunicabilidade à que estão compelidos os integrantes do júri popular, "[...] não podem dizer por que não podem pensar e, nesse contexto, estão excluídos do processo de integração social [...]” (RANGEL, 2005, p. 13).

Assim, nessa perspectiva, Paulo Rangel leciona que:

[...] a justificativa de que a incomunicabilidade é necessária para que um jurado não venha influir no voto do outro é falsa e desprovida de sentido e explicação histórica. Trata-se de uma medida arbitrária que não espelha a realidade do significado do tribunal do júri, enquanto instituição democrática, muito menos, hoje, alcança o estágio de civilidade vivido pelos cidadãos brasileiros. (RANGEL, 2005, p. 90)

A deliberação em grupo é apontada por Aury Lopes Júnior (2009, p. 316) como uma solução ao tribunal de júri, pois é a essência do Escabinado, que "[...] representa uma instituição superior ao júri, pois juízes leigos e técnicos atuam e decidem em colegiado”.

\subsubsection{A (im) parcialidade}

A imparcialidade é concebida doutrinariamente como um princípio supremo, pois, desde o momento no qual o Estado chamou pra si a tarefa de administrar a justiça, exige-se do órgão julgador um desinteresse de ambas as partes, com vistas à igualdade, ficando restrito ao interesse na resolução do conflito orientado pela busca da verdade processual ou melhor, na verossimilhança dos fatos pretéritos trazidos a lume.

Luigi Ferrajoli (2002, p. 464) leciona que a imparcialidade é imposta e exigida por se tratar da dedução substancial judiciária, que por objetivos externos, o julgador deve sujeitar-se apenas à lei, em decorrência da sua justificação e legitimação ético-política que provêm da "[...] perseguição da verdade e a tutela dos direitos fundamentais [...]”. 
Acrescenta o doutrinador que:

$\mathrm{O}$ juiz não deve ter qualquer interesse, nem geral nem particular, em uma ou outra solução da controvérsia que é chamado a resolver, sendo sua função decidir qual delas é verdadeira qual é a falsa. Ao mesmo tempo ele não ser sujeito representativo, não devendo nenhum interesse ou desejo - nem mesmo da maioria ou da totalidade dos cidadãos - condicionar seu julgamento que esta unicamente em tutela dos direitos subjetivos lesados. (FERRAJOLI, 2006, p. 464)

Decorrente desta premissa basilar, o Código de Processo Penal, em seu Art. 472, estabelece de maneira formal e solene, que os jurados, nominalmente irão responder ao juiz-presidende que, irão "em nome da lei" examinar a causa com imparcialidade, porém, "de acordo com vossa consciência", o que por si só é, em nossa concepção, representa uma contradição, pois não existe a menor possibilidade de limitação legal para um julgamento baseado e fundamentado apenas na consciência humana.

A imparcialidade decorre da eqüidistância entre as partes, limitadas e circunscritas às garantias e direitos subjetivos, o que, por muito resta afastado o júri popular, restando apenas, os julgamentos proferidos e fundamentados em seus sentimentos pessoais.

\subsubsection{A Ausência de Motivação}

Sobre o princípio da motivação das decisões judiciais, Luigi Ferrajoli preleciona que, este axioma:

[...] exprime e ao mesmo tempo garante a natureza cognitiva em vez da natureza potestativa do juízo, vinculando-o, em direito, à estrita legalidade, e, de fato, à prova das hipóteses acusatórias. É por força da motivação que as decisões judiciais resultam apoiadas, e, portanto, legitimadas, por asserções, enquanto tais verificáveis e falsificáveis 
ainda que de forma aproximada; que a 'validade' das sentenças resulta condicionada à 'verdade', ainda que relativa, de seus argumentos; que, por fim, o poder jurisdicional não é o 'poder desumano' puramente potestativo da justiça de cádi, mas é fundado no 'saber', ainda que só opinativo e provável, mas exatamente por isso refutável e controlável tanto pelo imputado e sua defesa como pela sociedade. Precisamente, a motivação permite a fundação e o controle das decisões seja de direito, por violação de lei ou defeito de interpretação ou subsunção, seja de fato, por defeito ou insuficiência de provas ou por explicação inadequada do nexo entre convencimento e provas. (FERRAJOLI, 2006, p. 497-498)

Na mesma esteira, Aury Lopes Júnior atribui a motivação das decisões a necessidade de limitação das decisões em face do devido processo legal, posto que, esta deve ser extraída de dentro do processo, ou seja, a verdade processual, é confirmada ou refutada a partir da motivação, que caracteriza a premissa básica da publicidade judicante.

Destarte, segundo o doutrinador:

Só a fundamentação permite avaliar se a racionalidade da decisão predominou sobre o poder, e, principalmente se foram observadas as regras do devido processo penal. Trata-se de uma garantia fundamental e cuja eficácia e observância legitima o poder contido no ato decisório. Isso porque, no sistema constitucional-democrático, o poder não esta autolegitimado, não se basta por si próprio. Sua legitimação se dá pela estrita observância das regras do devido processo penal, entre elas o dever (garantia) da fundamentação dos atos decisórios. (LOPES JUNIOR, 2008, p.195)

Vislumbrando a cadeia de significantes que impulsionam as decisões judiciais, Alexandre Morais da Rosa (2011, p. 43), leciona que o silêncio proporcionado pelo declínio da moti- 
vação judicial, confere a legitimidade para a abertura de um lócus onde se estabelecem os significantes inatingíveis pela obrigatória democratização do processo, pois "o que não se diz é frequentemente mais significativo do que o que se diz" (RAMALHO apud ROSA, 2011, p. 43).

Em uma demonstração inequívoca de que a instituição não se coaduna com o arcabouço constitucional conquanto diploma maior de onde se originam os direitos e garantias fundamentais, não apenas dos cidadãos, mas de todo ordenamento jurídico, além é claro, da sustentação do próprio ente estatal, retiramos do texto constitucional a obrigatoriedade da motivação oriunda do Art. 93, inc. IX, que reza:

Todos os julgamentos dos órgãos do Poder Judiciário serão públicos, e fundamentadas todas as decisões, sob pena de nulidade, podendo a lei limitar a presença, em determinados atos, às próprias partes e a seus advogados, ou somente a estes, em casos nos quais a preservação do direito a intimidade do interessado no sigilo não prejudique o interesse público à informação. (grifo nosso)

Esta possibilidade, concebida pelo princípio da Íntima Convicção, permite aos jurados, a possibilidade de atribuir à sentença "[...] o seu sentimento íntimo, com base em qualquer prova ou experiência pessoal, expressos ou não no processo. Não importando se há ou não provas nos autos" (RANGEL, 2007, p. 441 - 442), o que possibilita uma inimaginável amplitude ao julgador, podendo sentenciar com base intra ou extraautos, sepultando "[...] qualquer possibilidade de controle e legitimação desse imenso poder de julgar"( LOPES JUNIOR, 2009, p.312).

Por seu prisma, Fabrício Dreyer de Ávila Pozzebon (2006, p.247), acredita que a motivação (“garantia-mãe”), por ser um "[...] ponto de partida para a análise do respeito a todos os demais direitos constitucionais do acusado", possibilita a avaliação do exercício da atividade jurisdicional, verificando as 
escolhas e seleções feitas pelo julgador no momento de sentenciar, e que o dever de motivação possui três faces importantes:

a) Uma garantia de defesa contra eventuais abusos do poder estatal, uma vez que o Julgador deverá explicar os motivos que o levaram a decidir daquela forma (é um ponto de partida), além de possibilitar a interposição do recurso cabível; b) a materialização do direito subjetivo à prestação jurisdicional por parte do estado, após um procedimento marcado por garantias, as quais deverão estar traduzidas na fundamentação; e c) dever do estado prestála, assim como a educação, saúde, segurança, em primeiro e segundo graus de jurisdição, devendo o juiz atuar materialmente no sentido de sua efetivação (juiz ativo do Estado Democrático e Social de Direito), sempre sob pena de configuração da nulidade expressamente prevista no texto constitucional. (POZZEBON, 2006, p.247)

Sem a devida motivação, e consequentemente, sem a exposição pública dos fatos objetivos que levaram o corpo de jurados a decidir de tal forma, resta, com clareza palmar, que os julgamentos oriundos da instituição júri são puramente subjetivos, onde o que se julga é o autor do fato e não o fato do autor, contrariamente ao princípio da legalidade, e onde a lei não impõe parâmetros, abre-se espaço para as decisões discricionárias e arbitrárias, como aconteceu, por exemplo, com os regimes totalitários.

\section{A SELETIVIDADE PENAL EM PLENÁRIO}

O júri popular, nos moldes trazidos alhures, traz íncito a certeza que os julgamentos oriundos da instituição popular são puramente subjetivos, onde o que se julga é o autor do fato e não o fato do autor, contrariamente ao princípio da legalidade, e onde a lei não impõe parâmetros, abre-se espaço para as decisões discricionárias e arbitrárias, como aconteceu, por exemplo, com a inquisição e os regimes totalitários. 
Neste diapasão, a seletividade impera, pois os jurados possuem um pleno poder de distribuir o status de criminoso a uma parcela da sociedade, conforme o estereótipo lombrosiano, pois, de acordo com Alessandro Baratta:

As maiores chances de ser selecionado para fazer parte da "população criminosa" aparecem, de fato, concentradas nos níveis mais baixos da escala social (subproletariado e grupos marginais). A posição precária no mercado de trabalho (desocupação, subocupação, falta de qualificação profissional) e defeitos de socialização familiar e escolar,que são características dos indivíduos pertencentes aos níveis mais baixos, e que na criminologia positivista e em boa parte da criminologia liberal contemporânea são indicados como as causas da criminalidade, revelam ser, antes, conotações sobre a base das quais o status de criminoso é atribuído. (BARATTA, 2002, P. 165)

Se a verdade processual ou verossimilhança do fato pretérito (Gustavo Noronha de Ávila, 2006, p. 46), somente pode ser alcançada, segundo Luigi Ferrajoli (2002, p. 135) "[...] mediante as garantias ou regras do jogo codificadas, que asseguram essencialmente a possibilidade de refutar as hipóteses acusatórias [...]", haja vista que "ali onde a refutação é impossível significa que a técnica de definição legal e/ou judicial do que é punível não permite juízos cognitivos, mas apenas juízos potestativos, de forma que a livre convicção não se produz sobre a verdade, mas sobre outros valores" (FERRAJOLI, 2002, p. 135).

Significa dizer que nestes sistemas repressores, nos quais não há juízo de comprovação, mas de decisão, fundamentada unicamente na livre vontade dos jurados, opção puramente valorativa, apenas a defesa de sua classe social e a segurança dos sociáveis "homens de bem" que não serão selecionados e "[...] pegos pelas malhas da justiça [...]" (Alexandre Morais da Rosa, 2011, p. 22), há um julgamento inquisitivo, por ser inversamente proporcional a (in) segurança e a garantia da efetivi- 
dade dos direitos e garantias constitucionais (garantismo), pois enquanto um aumenta seu grau de eficácia, o outro diminui de forma imediata.

Outrossim, Luigi Ferrajoli defende que, nestes sistemas, o poder judicante é resultado do Poder de disposição, pois, este poder:

[...]é sempre o produto de carências ou imperfeições do sistema e como tal é patológico e está em contradição com a natureza da jurisdição. Seu exercício não pressupõe motivação cognitiva, mas apenas opções e/ou juízos de valor dos quais não é possivel qualquer caracterização semântica, mas apenas caracterizações pragmáticas, ligadas à obrigação da decisão. Propriamente, aqui não há sequer juris-dictio, isto é, denotação do que é conotado pela lei, mas simplesmente dictum". (FERRAJOLI, 2006, p. 134)

As decisões díspares com a norma constitucional são explicitadas por Paulo Rangel (2007, p. 480) ao declarar que: "no Júri, os iguais não julgam os iguais, basta verificar a formação do Conselho de Sentença: em regra, funcionários públicos e profissionais liberais. E os réus? Pobres". Aramis Nassif (2008, p. 43) por sua vez, expõe que o grande freqüentador do banco dos réus é o pobre, o marginal.

Neste contexto, o padrão e a imposição da "normalidade" são as premissas válidas, pois, como aponta Alexandre Morais da Rosa esse comportamento, herança do período inquisitivo, na realidade forense se assemelha ao conceito de "raça pura do nazismo", argumentando sua posição da seguinte forma:

a) eu sou normal e você doente; b) sendo superior, é meu dever moral desenvolver os mais primitivos; c) o padrão de normalidade é o meu; d) se o 'desviado' resiste à normalização, estou legitimado a excluí-lo, porque a pena é um tratamento em prol do próprio criminoso, é a cura; e) eventuais vítimas são necessárias à cura dos demais, no sentido de 
quase um ritual de sacrifício, até para impor um padrão de 'normalidade'; f) o 'criminoso' tem culpa de resistir e pela 'pena' pode ser perdoado; g) Ao final, neste processo de normalização, os custos - sofrimentos e sacrifícios - são inevitáveis e até mesmo necessários à cura dos primitivos. (ROSA, 2007, p. 325)

Ao atuar dessa maneira, o júri age, de acordo com Cesare Beccaria (2000, p. 59), contra aquele que perturba a tranqüilidade pública, que não obedece às leis, que viola as condições sob as quais os homens se sustentam e se defendem mutuamente, restando, pois, o dever de excluí-lo da sociedade, isto é, banido por não ser igual.

Inobstante ao supra exposto, o tribunal de júri se afasta do modelo acusatório inerente a um Estado Democrático de Direito e mantém um vínculo estreito de afinidade com o modelo inquisitivo, e por via direta, com um totalitarismo inaceitável.

Nesta toada, Salo de Carvalho (2008, p. 16) expõe que "o juízo inquisitorial abdica da cognição e, como efeito da falta de critérios objetivos, subjetiva a decisão e a aplicação/execução da pena desde uma perspectiva potestativa”.

No mesmo norte Ferrajoli (2006, p. 37), leciona que o efeito desta subjetivação é a "perversão inquisitiva do processo, dirigindo-o não no sentido da comprovação de fatos objetivos (ou para além delas), mas no sentido da análise da interioridade da pessoa julgada”.

Aury Lopes Júnior, correlaciona o princípio da íntima convicção ao arbítrio inquisitorial, pois, consubstanciada nesse "princípio", permite-se:

[...] a imensa monstruosidade jurídica de ser julgado a partir de elemento. Isso significa um retrocesso ao Direito Penal do autor, ao julgamento pela "cara”, cor, opção sexual, religião, posição socioeconômica, aparência física, postura do réu durante o julgamento ou mesmo antes do julga- 
mento, enfim, é imensurável o campo sobre o qual pode recair o juízo de (des)valor que o jurado faz em relação ao réu.

A inquisitoriallidade do júri é advertida pelo doutrinador ao dizer que "nem mesmo o catalão NICOLAU EYMERICH, o mais duro dos inquisidores, no famoso Directorium Inquisitorum, elaborado em 1376, posteriormente ampliado por Francisco de la Peña, em 1578, imaginou um poder de julgar tão amplo e ilimitado”. (LOPES JÜNIOR, 2011, p. 343)

\section{EXPOSIÇÃO DA PESQUISA NA COMARCA DE PALHOÇA/SC ${ }^{3}$}

Perseguindo as respostas ao questionamento originário, nos propomos a pesquisar na prática, de forma qualitativa, os julgamentos de alguns Conselhos de Sentença da Comarca de Palhoça/SC, com o fito de tentarmos estabeler um nexo entre as premissas originárias do júri e a realidade atual.

Nesta esteira, com os resultados derivados, podemos demonstrar se as concepções extra processuais e os aspectos pessoais dos acusados, constituem provas irrefutáveis contrarias aos réus, pois diante de tais formulações (pré) construídas a partir de uma série de (in)certezas e idealizações subjetivas dos jurados, não são externados, pois esta garantia, foi negada aos réus condenados pelo conselho popular.

\subsection{Qual é o Seu Grau de Instrução?}

De acordo com a história, conforme se observa no capítulo referente à origem da instituição, e a doutrina que defende os julgamentos populares, a justificativa primaz da existência e da continuidade da instituição é a igualdade, ou seja, o julgamento de iguais.

3 Pesquisa contemplada e financiada pelo Programa Universitário de Iniciação Científica (PUIC) da Universidade do Sul de Santa Catarina - UNISUL, apresentada na VI Jornada Unisul de Iniciação Científica e no XXIII Salão de Iniciação Científica da Universidade Federal do Rio Grande do Sul - UFRGS, em 2011. 
Entretanto, $54.9 \%$ dos jurados (28 jurados) possuem o $3^{\circ}$ grau completo; $37.25 \%$ (19 jurados) possuem o $3^{\circ}$ grau incompleto; e 7.84\% ( 04 jurados) possuem o $2^{\circ}$ grau completo.

Assim, não resta dúvida que não ocorre em plenário um julgamento entre iguais. Em sua esmagadora maioria, os réus são oriundos das periferias e subúrbios das cidades, não possuindo, não raras vezes, o ensino fundamental completo, enquanto os jurados são alistados entre os funcionários públicos, que possuem, como se vê, no mínimo, o $2^{\circ}$ grau completo.

Esta desigualdade material ultrapassa os limites da igualdade formal, e impede, assim como aos magistrados, de sopesarem esta desigualdade no momento de proferirem as sentenças, por não possuírem a visão e compreensão real da complexidade que envolve os acusados, sendo motivados e orientados por suas realidades que em muito se afastam daquela vivenciada pelos acusados. Esta desigualdade exposta em plenário, que evidencia o conflito entre os estratos sociais, é explanada por Paulo Rangel (2007, p. 512) ao sustentar que "[...] no júri, os iguais não julgam os iguais. Os jurados são pessoas que integram um determinado segmento da sociedade, em geral funcionários públicos ou profissionais liberais. Já os réus, normalmente, integrantes da classe baixa, moradores da favela [...]".

\subsection{Você Achou Justa a Condenação do Casal Nardoni, no Caso Isabela?}

68.62\% (35jurados) responderam que sim; 27.45\% (14 jurados) não opinaram, pois não conheciam detalhes do caso e $3.9 \%$ (02 jurados) não opinaram.

Explicita-se aqui a influência que a mídia exerce sobre a população geral, que acompanha os tele-jornais sensacionalistas, colocando em xeque a esperançosa imparcialidade inata ao ato judicante, que ao júri popular é negada, restando um julgamento viciado, e em vários casos, principalmente os amplamente noticiados pela mídia, o acusado esta previamente condenado. 
Salo de Carvalho ensina que este ceticismo decorre do sentimento de impunidade e da sensação de insegurança que por sua vez são ocasionados pelo pânico moral amplificado pela mídia, que transforma fatos ocasionais em epidemias, manipulando estes acontecimentos por meio de uma simbologia.

Assim, segundo o autor é:

Viável concluir, pois, que a formação do imaginário social sobre o crime, criminalidade e punição se estabelece a partir de imagens publicitárias, sendo os problemas derivados da questão criminal, não rara vezes, superdimensionados. A hipervalorização de fatos episódicos e excepcionais como regra e a distorção ou incompreensão de importantes variáveis pelos agentes formadores de opinião pública, notadamente os meios de comunicação de massa, densificam a vontade de punir que caracteriza o punitivismo contemporâneo. (CARVALHO, 2010, p. 32)

Alexandre Morais da Rosa (2004, p. 232) adverte que a política romana do pão e circo (modernizada sob contornos televisivos) influi de tal modo que desvirtua a realidade, fomentando a obsessão punitivista-retributista dos "juízes midiáticos" que fazem dos programas "sangue-show" o principal atrativo televisivo, capaz de reunir toda família e mesmo a comunidade em torno da exigência penal.

Outrossim, o doutrinador ainda estabelece a influência da mídia no comportamento da população impulsionada pela sensação de insegurança, sendo que:

No tocante aos crimes, melhor se forem "bárbaros", por não envolverem disputa, pois ao invés de dividir - todos querem Justiça! - formarão consenso sobre a pena, e interessar à população jogada na "inautenticidade do a gente" (Heidegger), podendo ocasionar mobilizações em prol do único remédio conhecido - por eles - para conter a "chaga do crime": cadeia neles!; se possível linchamento em praça pública, com hora marcada, 
fogueira, enxofre, muito sangue e patrocinadores a peso de ouro, retomando-se o suplício do corpo dos condenados. (ROSA, 2004, p. 234)

Denota-se assim que, o cometimento de um crime capaz de comover a população serve de base para fomentar essa vontade de punir da população, cujo clamor é puxado pelos defensores da tolerância zero.

\subsection{Diante da Realidade dos Estabelecimentos Penais, Provisórios ou Permanentes, Você Acredita que é Possível Afirmar que as Periferias das Cidades, são Pólos Formadores de Criminosos?}

76.47\% (39 jurados) responderam que sim; 19.6\% (10 jurados) acreditam que; e 3.9\% (02 jurados) não opinaram.

Denotasse assim, que a seletividade penal não é apenas uma criação teórica, o status de criminosos recai, de fato, em uma parcela da sociedade. $\mathrm{O}$ fato de ser originário das áreas de exclusão, transforma os acusados em criminosos, ratificando a segregação social, que importa em manutenção das classes em seus limites delimitados pelo monopólio que a classe elitizada possui na possibilidade de ascensão social, pois os estereótipos criados historicamente e difundidos pelo mídia, impulsionam os julgamentos na medida em que impedem a refutação destas decisões pré-determinadas pelos preconceitos, principalmente se tratando de julgamentos que não são motivados.

Nesta contraposição de comportamentos, os estereótipos surgem como uma resposta imediata ao quesito "quem é o culpado?", gerando uma presunção absoluta embasada na supremacia de suas decisões que decorre de uma eloqüente responsabilidade penal subjetiva, sem considerar o fato de que "[...] no interior de uma sociedade moderna existem, em correspondência à sua estrutura pluralista e conflitual, em conjunto com valores e regras socais comuns, também valores e regras específicas de grupos diversos ou antagônicos [...]” (BARATTA, 2002, p. 75). 


\subsection{Você Acha que, Independentemente do Contexto Sócio-econômico-político-cultural e do Oferecimento de Oportunidades, Há Pessoas Propensas ao Cometimento de Delitos-crimes?}

92.15\% (47 jurados) responderam que sim; 5.88\% (03 pessoas) responderam que não;e, 1.9\% (01jurado) não soube responder.

O resultado não deixa dúvidas, a quase unanimidade do conselho de sentença composto por juízes leigos mantém viva a teoria de Lombrosiana que, mormente conduzem a persecução penal, pois a teoria do delinqüente nato, aquele indivíduo que possui o DNA criminoso, transmissível hereditariamente aos descendentes, continua a fundamentar as sentenças.

Nesta dicotomia entre patologia e profilaxia, estes indivíduos "doentes" e disseminadores da "anormalidade" que o crime configura, devem ser segregados da sociedade antes que se multipliquem, pois a seleção natural humana se encarregou de definir quem são os indivíduos aptos e merecedores da convivência social, superiores de fato.

Outrossim, Salo de Carvalho confere ao discurso científico que estabeleceu a inferioridade bio-psico-antropologica, oriunda da escola Positiva italiana, a irrefutável superioridade europeia branca, tendo em vista a iminente regressão aos primórdios primitivos que o "delinquente nato" representava, a anomalia craniana inegável induziria os homems ao perído anterior ao pacto vital para a sua civilização, determinando assim, o seu retorno ao estado natural: o lobo (homo criminalis), pois:

A mudança de objeto - da lei ao homem delinqüente - condiciona uma mudança radical de método - do lógico aristotélico (dedutivo) ao indutivo experimental (empirista) -, e do acertamento processual dos casos penais - do modelo cognoscitivista jurisdicional ao decisionismo valorativo substancialista. Do estudo das relações objetivas e subjetivas entre o fato e o resultado, a ciência 
penal parte para anamnese reconstrutiva da personalidade do indivíduo desde os seus primórdios, julgando e punindo sua história de vida. A um direito penal do fato-crime se sobrepõe um direito penal do autor fundado na periculosidade, independente da relação de proporcionalidade entre a lesão do bem jurídico tutelado e a norma jurídica. (CARVALHO, 2008, p. 59-60)

Inexorável, portanto a imposição da classe dominante e seleta, biológica e fisiologicamente, de usufruição de sua vontade racional sob a pretensão de expurgar o mal estereotipado, ainda mais que esse gene, deveras perigoso e aniquilador do homo sapiens, se prolifera com muito mais facilidade em ambientes pobres, onde a relação atávica primitiva encontra um meio favorável para a proliferação, razão pela qual deve-se isolar esses indivíduos, até o momento em que apenas exista o DNA bom.

Alexandre Morais da Rosa leciona que:

Com isso, a sociedade está legitimada a "seqüestrar" o criminoso em face dos temíveis efeitos sociais/ morais que pode causar, tudo - cinicamente - em nome da "paz social" e "segurança jurídica", tecnicamente chamada de Defesa Social. [...] Alicerçados sobre o medo, o temor do delinqüente, a Defesa Social mantém a estrutura de perscrutar o "criminoso" na sua subjetividade e construir mecanismos de proteção da sociedade contra o inimigo, com a respectiva individualização da pena, que ainda perdura. $\mathrm{O}$ criminoso em não sendo um igual, se considerada a divisão entre o mundo dos bons e dos maus, pode e deve, na lógica da Defesa Social, ser liquidado ou reformado para ser igual aos bons, os que se impõem pela força. Para além da punição, articulam-se estratégias preventivas e terapêuticas. (ROSA, 2004, p. 214 e 216)

Esses "defeitos de personalidade" provocados pela presença genética do DNA/crime fundamentaram o direito penal do 
inimigo que por sua vez, fundamentou a teoria da Defesa Social que por meio do medo social, da promessa da paz social e da natureza e vontade punitivista da população, impulsionam a política de tolerância zero.

\subsection{Com Base na sua Experiência de Vida, é Possível Visualizar, Mesmo que de Forma Superficial e Momentânea, Quem é Culpado ou Inocente?}

$60.78 \%$ (31 jurados) responderam que sim e 39.2\% (20 jurados) responderam que não.

A questão apresentada, mantém uma relação direta com a antecedente, cujo objetivo era a ratificação da teoria lombrosiana que possui uma origem inata ao indivíduo predeterminado ao e a exteriorização desta característica (via aspectos físicos que refere-se ao aspecto fisionômico do criminoso nato amplamente difundido e com características físicas bem delineadas que por evidente, se distanciam das características físicas dos julgadores e da classe à qual estes pertencem).

Assim, as respostas exaradas demonstram a força que o estereótipo criminal possui nos julgamentos, ratificando a prevalência do direito penal do autor, onde a aparência ganha status de prova inequívoca da culpabilidade do acusado e da veracidade irrefutável que autolegitima a pena. Assim, os julgamentos são orientados pela cara do acusado em contraste com a imagem estereotipada do criminoso, sendo que é na aparência, composta pelas características físicas, vestuário, calçados e posição social, que se distingue quem é inocente e quem é culpado.

Nesta perigosa seara, a aparência do acusado influi de maneira primordial na formulação da decisão penal, ignorando as influências culturais e sociais dos acusados provenientes das zonas de exclusão sociais e reduzindo o princípio da liberdade, posto que em plenário, os acusados não podem se vestir de qualquer maneira, sendo que o conflito entre a aparência do (a) normal, se opera a partir da "cadeia de significantes" que variam conforme o humor (Alexandre Morais da Rosa, 2011a, p.41). 


\subsection{Na Sua Opinião, Quem Seria o Provável Culpado do Cometimento de um Crime, Uma Pessoa Com Várias Passagens Pela Polícia, Ex-penitenciário ou uma Pessoa Que Nunca Cometeu Qualquer Crime?}

$50.98 \%$ (26 jurados) responderam que o reincidente seria o provável culpado; 07.84\% (04 jurados) acreditam que o réu primário teria uma maior probabilidade de ser o autor de um crime; $21.56 \%$ (11 jurados) não responderam; 13.72\% (07 jurados) responderam que independe da situação; e, 03.10\% (02 jurados) acham que o determinante é a natureza do crime, ou seja, depende do crime.

Nota-se que a situação do acusado que é reincidente é determinante na sentença, inferindo-o a prova, presumida, de sua culpabilidade, que perante o tribunal do júri, não pode ser refutada, elevando esta presunção, decorrente de um explícito bis in idem, ao patamar de absoluta ("juris et de jure"), uma vez que, sob a égide da ausência de motivação, este exercício de "achismo" é (re)coberto com o véu da (in)certeza dos reais motivos ensejadores da decisão.Desta monta, a presunção de culpabilidade se sobrepõe sobre o princípio constitucional da presunção de inocência, que em verdade, é a única presunção possível pelo Texto Maior, resulta em uma analogia defectiva, substituindo culpabilidade por reincidência.

Neste diapasão, Alexandre Morais da Rosa estabelece que:

Os antecedentes se constituem, pois, na "ficha de pecados" do acusado [...]. O condenado jamais se livra da sanção, servindo para sempre e sempre lhe recrudescer a resposta estatal, sendo que tal raciocínio vigora no Brasil. [...] na prática jurídica há um imbricamento entre culpabilidade e periculosidade, medindo-se a primeira conforme a lista do que se chama antecedentes, transformados "no sintoma de uma personalidade perigosa". Nesse momento o autor que passa a ser julgado não pelo que fez, mas pelo que fez no passado e é, em franca violação dos postulados garantistas, funcionando 
muitas vezes para sustentar a condenação no caso de ausência de certeza. Isto é, em caso de dúvida, consulta-se inconstitucionalmente os antecedentes e se existirem, o julgamento pode acabar em condenação, aplicando-se um indutivismo ingênuo. (ROSA, 2004, p. 349-351)

A dependência causal entre a condenação e a reincidência, que se configura como continuação do processo de etiquetamento social, é estabelecida por Alessandro Baratta ao dizer que:

A teoria das carreiras desviantes e do recrutamento dos "criminosos" nas zonas sociais mais débeis encontra uma confirmação inequívoca na análise da população carcerária, que demonstra a extração social da maioria dos detidos dos estratos sociais mais inferiores e o elevadíssimo percentual que, na população carcerária, é representada pelos reincidentes. (BARATTA, 2002, p. 179-180)

Assim, a periculosidade abstrata representada pela reincidência do acusado é a prova cabal de sua culpa, se, a ele for imputado outro delito, seguindo a equação maniqueísta: reincidente $=$ culpado, que se apresenta como uma "verdade real" encontrada em um processo anterior, sendo desnecessário um novo processo para dizer o óbvio (?).

\subsection{Você Acha Que os Presídios Servem Para Re-educar, Ressocializar os Indivíduos?}

$3.9 \%$ (02 jurados) responderam que sim; 94.11\% (48 jurados) responderam que não; e o $1.9 \%$ restante (01 jurado) respondeu que apenas os presídios que possibilitam o trabalho.

A teoria mista que é adotada pelo Brasil tem na pena a idéia da sanção justa e útil, ou seja, a pena necessária, objetivando quatro finalidades: a prevenção, a retribuição, a ressocialização e a re-educação.

Em que pese a desconstrução das teorias das penas em seus objetivos de ressocialização e re-educação, o próprio júri 
explicita a iníqua perseguição á esses fins, restando apenas a retribuição. Cezar Roberto Bitencourt alerta que o problema da ressocialização não pode ser resolvido com fórmulas simplistas, sob pena de termos resultados insatisfatórios. Para o autor, a finalidade ressocializadora não é a única e nem mesmo a principal finalidade da pena, sendo apenas concebível a sua perseguição na medida do possível, posto que:

Modernamente, só se concebe o esforço ressocializador como uma faculdade que se oferece ao delinquente para que, de forma espontânea, ajude a si próprio a, no futuro, levar uma vida sem praticar crimes. Esse entendimento configura aquilo que se convencionou chamar "tratamento ressocializador mínimo". Afasta-se definitivamente o denominado objetivo ressocializador máximo, que constitui uma invasão indevida na liberdade do indivíduo, o qual tem o direito de escolher seus próprios conceitos, suas ideologias, sua escala de valores. (BITENCOURT, 2008, p. 124)

Se $94.11 \%$ dos jurados que compuseram os conselhos de sentença não acreditam nos objetivos da pena, resta claro que as condenações possuem somente um objetivo: a retribuição, esta força propulsora que substitui a vindita do Leviatã. O objetivo real das penas, a retribuição, a mesma desde o medievo, mormente promovida pela Inquisição é demonstrada por Michel Foucault, que, ao se referir aos suplícios públicos, traça um paralelo com as condenações atuais, ao relatar que:

O suplício tem então uma função jurídico-política. É um cerimonial para reconstruir a soberania lesada por um instante. [...] Sua finalidade é menos de estabelecer um equilíbrio que de fazer funcionar, até um extremo, a dissimetria entre o súdito que ousou violar a lei e o soberano todopoderoso que faz valer sua força. Se a reparação do dano privado ocasionado pelo delito deve ser bem proporcionada, se a sentença deve ser justa, a execução da pena é feita para dar não o espetáculo 
da medida, mas do desequilíbrio e do excesso; deve haver nessa liturgia da pena, uma afirmação enfática do poder e de sua superioridade intrínseca. (FOUCAULT, 1999, p. 42)

Outrossim, Alexandre Morais da Rosa (2011, p. 23) salienta a função retributiva da dogmática penal, ao estabelecer que "pulso forte na esfera penal e infracional é o discurso atual. A reação às violações da norma acabam sendo violentas e na maioria das vezes, como os resultados mostram, ineficazes. Podem ser eficientes para o aniquilamento, ou seja, a morte de muitos condenados".

\subsection{Você Acha Que Menoridade Penal Deveria Ser Reduzida?}

$72.54 \%$ (37 jurados) responderam que sim; enquanto de $27.45 \%$ (14 jurados), responderam que não.

O sistema penal brasileiro, ao definir a maioridade penal aos 18 anos, escolheu o sistema biológico para a presunção legal de incapacidade de discernimento necessário para a imputação das sanções decorrentes de fatos típicos, não considerando o desenvolvimento mental e a capacidade plena de entendimento do ilícito penal. Essa escolha foi decorrência de uma política criminal, que estabeleceu, a partir de sua opção, a "[...] presunção absoluta de inimputabilidade [...]”(BITENCOURT, 2008, p.357). .

Assim, o Direito Penal ainda é visto pelo Conselho de Sentença como primeira e única resposta ao fato social-crime, ignorando o seu primado de intervenção mínima e de última ratio, ou seja, como o último recurso decorrente da vergonhosa história das penas, o que lhe outorga o poder de "acabar com o mal pela raiz", pois pelo senso comum, a impunidade conhecida pelos menores lhes proporciona a faculdade de cometer crimes e não irem presos, tendo em vista que o ECA, protege-os da justiça, possibilitando estes jovens desenvolverem com êxito uma carreira criminosa. 


\subsection{Você Acha Que a Pena de Morte Deveria Ser Inserida no Brasil?}

50.98\% (26 jurados) responderam que sim; 43.13\% (22 jurados) responderam que não; 1.9\% (01 jurado) respondeu que é a favor em alguns caos; outros 1.9\% (01 jurado) defende a pena de morte nos caos de estupro; e 5.88\% (03 jurados) não opinaram.

Muitos fatores impedem a reinserção da pena de morte no Brasil. A Declaração Universal dos Direitos Humanos, em seu Art. 3', garante o direito à vida a toda pessoa, Nossa Carta Política deixa clara a posição humanista quando estabeleceu, como cláusula pétrea, em seu Art. 5, inc. XLVII, “a”, que não haverá pena "de morte, salvo em caso de guerra declarada, nos termos do Art. 84, XIX”. Assim, a pena letal se restringe aos casos de guerra, ocorrendo agressão estrangeira, cuja declaração é competência privativa do Presidente da República, dependendo ainda de autorização ou referendo do Congresso Nacional.

Entretanto, em que pese os riscos intrínsecos à pena de morte, além da irracionalidade, a maioria dos jurados declara que é favorável a ela, o que traduz que, se fosse cominada a pena capital para delitos, muitos acusados estariam condenados à morte pelo "sim" executório dos conselhos.

\section{CONCLUSÃO}

Em que pese o considerável lapso temporal que se apresenta em milênios desde a controvertida origem das raízes estruturantes da instituição do tribunal do júri até os dias atuais, a instituição se fundamenta ainda em uma ingênua e ilusória possibilidade de uma justiça tangível, advinda do julgamento de juízes leigos por estes serem "semelhantes" aos acusados, sendo que esta "igualdade" basta para a perquirição incontroversa.

Nesse contexto, ao perseguir a justiça, retirando o poder de decisão dos soberanos e dos déspotas, ou de seus delegados, a instituição do júri se revelou como um importante marco histórico para a humanização das penas. 
Entretanto, com o decorrer de séculos, a instituição, nos moldes que se apresenta, quase intangivel, se mostra hoje, incompatível com os ideais estabelecidos por um Estado Democrático de Direito, todavia, por uma escolha política menos apurada do Legislador Ordinário, o júri foi elevado a clausula pétrea.

Destarte, os princípios conferidos à instituição do júri pela Constituição e pelo CPP ignoram todo o arcabouço, igualmente constitucional ,de garantias e direitos que limitam a atuação estatal na persecução penal.

A amplitude de julgamento conferida aos jurados, que não pode ser refutada ou mesmo confirmada, confere a seletividade inegável de suas decisões, pois, o status de criminoso é distribuído com base na aparência e na origem do acusado, um exercício lombrosiano que confere uma inquisitorialidade explícita ao processo que se quer acusatório, julgando pois, o autor do fato e não o fato do autor.

Abstract: There is no consensus on the literature about he origin of the jury. Inobstante to its exact origin, the jury is born, just attempting to limit the power of the vengeful ruler. Despite the time gap that separates realities, the institution relied upon by the same premises, maintaining the illusion that it is capable to reach justice. In this vein, the jury in current patterns, is inconsistent with the guarantees that sustains a democratic state, mainly because of one of its founding basis: the subjectivity of the decisions. This aspect leverages the trial of the perpetrator, resulting therefore in an inquisitive selectivity, based on the stereotype of the "criminal".

Keywords: Grand Jury. Criminal proceedings. Criminology. Selectivity. Stereotype. 


\section{REFERÊNCIAS}

ANDRADE, Mauro Fonseca. Sistemas processuais penais e seus princípios reitores. Curitiba: Juruá, 2009.

ÁVILA, Gustavo Noronha de. A obsessão pela "verdade" e algumas de suas conseqüências para o processo penal. In: AZEVEDO, Rodrigo Ghiringhelli de. CARVALHO, Salo de. A crise do processo penal e as novas formas de administração da justiça criminal. Sapucaia do Sul: Notadez, 2006. p. 41- 47.

FERRAJOLI, Luigi. Direito e razão: teoria do garantismo penal. 2. ed. rev. e ampl. São Paulo: Revista dos Tribunais, 2002.

NUCCI, Guilherme de Souza. Tribunal do júri. São Paulo: Revista Dos Tribunais, 2008.

RANGEL, Paulo. A inconstitucionalidade da incomunicabilidade do conselho de sentença no tribunal do júri brasileiro. 2005. 157 f. Tese (Doutorado) - Curso de Direito, Departamento de Ciências Jurídicas e Sociais, Universidade Federal do Paraná, Curitiba, 2005. Disponível em: <http://dspace.c3sl. ufpr.br/dspace/bitstream/1884/2619/1/paulorangel.pdf>. Acesso em: 13 abr. 2011.

Direito processual penal. 12. ed. rev, ampl. e atual. Rio de Janeiro: Lumen Juris, 2007.

Direito processual penal. 15. ed. rev, ampl. e atual. Rio de Janeiro: Lumen Juris, 2008.

TOURINHO FILHO, Fernando da Costa. Processo penal. 30 ed. rev. e atual. São Paulo: Saraiva, 2008. 4 v.

FOUCAULT, Michel. Vigiar e punir: nascimento da prisão. 21. ed. Petrópolis: Vozes, 1999

NASSIF, Aramis. Júri: instrumento da soberania popular. Porto Alegre: Livr. do Advogado, 2008.

OLIVEIRA, Eugênio Pacelli de. Curso de processo penal. 10 ed. atual. Rio de Janeiro: Lumen Juris, 2008.

LOPES JUNIOR, Aury. Direito processual penal e sua conformidade constitucional. 3. ed. rev. e atual. Rio de Janeiro: Lumen Juris, 2008. 1 v. 
Direito processual penal e sua conformidade constitucional. Rio de Janeiro: Lumen Juris, 2009. 2 v.

Direito processual penal e sua conformidade constitucional. 6. ed. atual. Rio de Janeiro: Lumen Juris, 2011. 2 v.

BARATTA, Alessandro. Criminologia crítica e crítica do direito penal. 3. ed. Rio de Janeiro: Revan: Instituto Carioca de Criminologia, 2002.

BECCARIA, Cesare. Dos delitos e das penas: texto integral. São Paulo: M. Claret, 2003.

CARVALHO, Salo de. O papel dos atores do sistema penal na era do punitivismo. Rio de Janeiro: Lumen Juris, 2010.

2008 .

Pena e garantias. 3. ed. rev. e atual. Rio de Janeiro: Lumen Juris,

ROSA, Alexandre Morais da. Decisão no processo penal como bricolage de significantes. 2004. 420 f. Tese (Doutorado) - Curso de Direito, Departamento de Ciências Jurídicas e Sociais, Universidade Federal do Paraná, Curitiba, 2004. Disponível em: <http://tjsc25.tj.sc.gov.br/ academia/cejur/arquivos/decisao_processo_penal_alexandre_rosa.pdf $>$. Acesso em: 03 fev. 2011.

Jurisdição do real $x$ controle penal: direito $\mathcal{E}$ psicanálise, via literatura. Petrópolis: Delibera/kindlebookbr, 2011.

O papel do juiz garantista e a execução penal em tempos neoliberais: Eichmenn e big brother. In: CARVALHO, Salo de (Org.). Crítica a execução penal: doutrina, jurisprudência e projetos legislativos. 2. ed. rev., ampl. e atual. Rio de Janeiro: Lumen Juris, 2007, p. 319 - 348.

POZZEBON, Fabrício Dreyer de Ávila. A crise do conhecimento moderno e a motivação das decisões judiciais como garantia fundamental. In: GAUER, Ruth Maria Chittó (Coord.). Sistema penal e violência. Rio de Janeiro: Lumen Juris, 2006, p. 231 - 247. 